Article by an MPIfG researcher

Imke Kruse: EU Readmission Policy and its Effects on Transit Countries: The Case of Albania. In: European Journal of Migration and Law 8(2), 115-142 (2006). Brill

The original publication is available at the publisher's web site: http://dx.doi.org/10.1163/157181606777974950

\title{
EU Readmission Policy and its Effects on Transit Countries - The Case of Albania
}

\author{
IMKE KRUSE*
}

\section{Introduction}

In 2002, the Commission reported that of the thirteen million refugees world-wide only 15 percent resided on EU territory and that over the last decade the number of asylum seekers arriving in the EU had halved. ${ }^{1}$ Nevertheless, the political debates in EU Member States as well as on EU level have become increasingly dominated by the perception of the continent being "overwhelmed" by immigrants. Currently, it seems much easier for Member States to agree upon exclusionary measures like harsher border controls, return policies, visa requirements and carrier sanctions than on issues concerning refugee protection and the creation of a common asylum system. Between 1999 and 2001, the European Commission adopted a set of proposals concerning legal immigration, refugee protection and the creation of a common European asylum system. However, Member States strongly resisted most of these proposals and achieved substantial revisions and tightening before finally adopting some of them, and only under high time pressure. Meanwhile, since 2001 the Commission has turned substantial parts of attention to illegal migration, and discussions on migration and asylum became publicly interlinked with questions of internal security and terrorism. Already in 1998 the Austrian Presidency had stated:

"Political interest is no longer focused so much on asylum questions and problems of temporary protection, but more on general questions of migration, problems of combating facilitator networks and expulsion issues. (...) In the light of the greater proportion of illegal immigrants and the high professionalism of facilitator organisations, this aspect now has particular priority" (Council of the European Union 1998b).

When the Amsterdam Treaty deadline ended in May 2004, only three of the envisaged four main legal instruments on asylum had been adopted: the reception conditions directive, the qualification directive and the Dublin II regulation. Negotiations on the asylum dossiers have been very tedious and have often taken months if not years. The reception conditions directive is a point in case for a harmonisation on low level. Even more, for a long time no agreement had been reached on the asylum procedures directive which was only adopted at the Justice and Home Affairs Council in December 2005. ${ }^{2}$

\footnotetext{
* Max Planck Institute for the Study of Societies, Cologne, Germany.

${ }^{1}$ Cf. Commission of the European Communities 2002b: 13.

2 For an in-depth analysis of the shifting focus from legal immigration and asylum to restrictive measures on border control, illegal migration and return, see Kruse 2005.
} 
In the area of legal migration progress has been even scarcer: the Council adopted directives on family reunification, admission of students and on the long-term resident status but no progress has been made with regard to economic migration and the integration of migrants. The directive on family reunification is an additional example for low level harmonisation. A Commission proposal for a directive on entry and residence conditions for labour immigrants remained largely unaddressed by the Council. ${ }^{3}$

Niessen (2004: 42-45) offers two reasons for the fact that no real common European migration and asylum policies have been created during the last five years. First, Member States proved reluctant to share sovereignty and for a long time did not introduce majority-voting to decision-making on migration and asylum issues. ${ }^{4}$ Secondly, asylum and migration were still perceived as predominantly negative issues, and the arrival of people - be they refugees, illegal migrants or family members - generally was not welcome. In consequence, European politics were reactive not proactive and were perceived as crisis management dealing with unwanted arrivals. The terrorist attacks in the US and Spain strengthened this perception and made asylum and migration even more associated with external threats, crime and security. Accordingly, progress in co-operation has primarily been made with regard to illegal migration. Besides many other documents, the Council adopted three action plans on the fight against illegal migration, control of external borders and return policy.

Right after the May 2003 terrorist attacks in Casablanca the five biggest EU Member States - Germany, France, the UK, Italy and Spain - brought into being a so-called "G5" framework to discuss questions of terrorism, organised crime and illegal immigration. During several intergovernmental meetings, interior ministers of these countries agreed on a number of measures against illegal immigration, discussed the creation of a common "safe countries" list, the incorporation of digital fingerprints into visas and joint negotiations of readmission agreements with countries of origin and transit instead of EU-level negotiations. They blamed the Commission for progressing too slowly in the area of illegal migration. However, even though the emphasis on internal security, crime and terrorism reinforced the predominance of topics such as access restriction and the so-called "fight" against illegal migration on European level, the preoccupation with migration control already started in the 1970s. Its intensification in the 1990 s actually pre-dated the new security agenda of the post-9/11 period. ${ }^{5}$

\footnotetext{
${ }^{3}$ Cf. Commission of the European Communities 2001b.

4 The Member States decided to introduce qualified majority voting from January 2005 onwards only with regard to the following areas: examination of visa applications, border checks and surveillance, measures setting out conditions under which third country nationals have freedom to travel within EU territory during a period of up to three months, measures promoting a balance of efforts between Member States in receiving refugees and displaced persons, and measures on illegal immigration and illegal residence, including repatriation of illegal residents. Immigration and asylum remain under unanimity voting until such time as the new Constitutional treaty should take effect (cf. Council of the European Union 2004b).

5 Mitsilegas (2002) e.g. speaks about the "securitization" of migration issues with regard to the Maastricht Treaty; Cholewinski (2000) discussed the security focus in the EU's policies on illegal migration already before the terrorist attacks. Regarding the so-called "securitization" of migration policies see e.g. Bruggeman 2002; Guiraudon/Lahav 2000; Huysmans 2000; Lavenex 2000.
} 


\section{EU READMISSION POLICY \& ITS EFFECTS ON TRANSIT COUNTRIES}

EU policies related to border control, immigration restrictions and return of illegal migrants and rejected asylum seekers by definition need the co-operation of bordering countries to be effective. Therefore, the EU seeks to expand her legal boundaries to non-member countries in geographic proximity. This means that internal policies especially if of great concern to Member States' citizens and their identity - have started to shape the Union's policy towards the outside. One issue area, which is gaining increasing importance in the Union's external relations, is return policy, particularly the instrument of readmission. By analysing the consequences of EU readmission policy for transit countries in geographic proximity, this paper sheds light on a mostly ignored fact of Europeanisation, its impact on non-EU countries.

I start with an analysis of common return policies to explain the characteristics of the instrument of readmission and its supposed legitimacy. On that basis, the third section examines the readmission negotiations between the EU and Albania and explains why these negotiations proceeded so smoothly. Even though negotiations were not tough, it would be misleading to assume that the Albanian government did not get anything in return for signing the agreement. The analysis shows that if the EU seeks to transfer rules which do not entail any advantages for the respective non-Member State, cooperation will only be possible if she offers some sort of compensation which is high enough to change the cost-benefit analysis of negotiation partners by balancing out the negative consequences of cooperation. In the Albanian case, the country has an undisputed long-term EU membership perspective for which it needs to show strong cooperative behavior and willingness to introduce EU rules and laws. In that context, the Albanian authorities took the readmission agreement as just one out of many obligations to meet on their way to EU integration. Section four investigates the challenges Albania is facing in order to implement the EU readmission agreement and discusses possible negative effects of this EU policy for a non-member country. Even though the focus lies on the Albanian case, this section makes clear that these challenges generally concern transit countries and, thus, are more or less the same for all transit countries the EU is negotiating readmission agreements with. The paper concludes with some more general thoughts on the effectiveness of readmission policy.

\section{Common Return Policies}

Return basically means going back from a country of presence to the country of origin or to a country of previous transit. Sub-categories of return specify the way it takes place (voluntary, forced, assisted or spontaneous return) and who participates (e.g. the term "repatriation" refers to refugees only and "expulsion" relates to third-country nationals who constitute a threat to public order or national security). Voluntary return requires an informed and free decision taken by the individual, and assisted voluntary return refers to organisational and financial assistance for return (sometimes including reintegration measures). Voluntary return might take place under compulsion when persons at the end of their temporary status or those rejected for asylum choose to return on their own volition. In contrast, involuntary or forced return takes place without the individuals' decision to return. In that case, state authorities decide to force the return 
and sometimes even escort the migrant home. In the literature, the terms involuntary or forced return are often used interchangeably with deportation and expulsion.

During past years, return migration has emerged as an important element of migration policy in EU Member States. ${ }^{6}$ Many governments see it as a core element of any successful strategy to prevent or deter illegal migration and residence in EU territory. ${ }^{7}$ They further argue that the forced return of migrants serves to maintain the integrity of asylum seekers and regular immigration programmes and underlines the states' sovereign right under international law to decide who should enter and stay within their territories. To achieve higher numbers of returns, countries introduce or extent the number of places in detention centres, accommodate rejected asylum seekers in return centres, and reduce or remove welfare benefits from rejected asylum seekers.

According to IOM (International Organization for Migration 2004b: 7), forced and voluntary returns have been proven to be interlinked in that voluntary return has been most successful where involuntary return is also carried through. Generally, assisted voluntary return is seen as a preferred return option because it is more cost effective, humane and productive in terms of good relations with countries of origin and transit. It is further assumed that assisting countries of origin in their efforts to reintegrate returned migrants functions as an incentive for other illegal migrants to return home voluntarily and for returned migrants to stay home. In this sense, voluntary return especially assisted voluntary return - has proven to be a more durable solution than forced return. While in the early 1990s only four assisted voluntary return programmes existed in Europe, by the beginning of 2004 there were more than 20 such programmes in 18 European countries.

During last years the EU has sought to strengthen co-operation with countries of origin and transit of illegal migrants, and readmission agreements feature as prime instrument. In 2002, the European Commission prepared a Green Paper on a Community Return Policy in which the Commission emphasised that a return policy for rejected asylum seekers is necessary in order to safeguard the integrity of an EU asylum system. ${ }^{8}$ Even though priority should be given to voluntary return, forced returns may be necessary as a last resort. The Green paper called attention to human rights issues in the context of return, e.g. that illegal residents must have adequate opportunities to lodge an appeal before a court during the return procedure.

In November 2002 the Council adopted a Community return action programme. ${ }^{9}$ It consists of four elements: (a) practical co-operation including exchange of information and best practices, common training, mutual assistance by immigration officers and joint return operations; (b) common minimum standards for return; (c) country specific programmes; and (d) intensified co-operation on return with third countries. In 2004, the Commission announced the setting up of a $€ 30$ million framework prepara-

\footnotetext{
${ }^{6}$ For details on various (assisted) voluntary return programmes and the use of forced return in EU Member States, see International Organization for Migration 2004b; Gibney 2003; International Organization for Migration 2001; Koser 2000.

7 The 1994 communication on immigration and asylum policies also identified the return of illegal migrants as a key instrument to reduce illegal migration; cf. Commission of the European Communities 1994: 30-31.

${ }^{8}$ Cf. Commission of the European Communities 2002c.

${ }^{9}$ Cf. Council of the European Union 2002e.
} 
tory action for return covering transportation and integrated return programmes to run during 2005 and 2006. ${ }^{10}$ The Council agreed upon preparatory actions for a financial instrument for return management. ${ }^{11}$ At the end of 2004, the Commission took stock of the Union's efforts to create common return policies:

"In the field of return of third country nationals there is still much work to be done. Thus, there are no harmonised conditions and procedures for the return of people staying illegally in the EU. (...) The success of the return policy (. . .) depends heavily on the co-operation of third countries, which is directly reflected in the progress of the readmission agreements. The readmission agreements as well as the entire migration dialogue with third countries is characterised by the need for strong coordination of the external relations of the EU. Such co-ordination leads to the necessary bundling of forces and render the EU action vis-à-vis the third countries more coherent and efficient" (Commission of the European Communities 2004: 19).

Readmission is the main instrument of return, and the EU has recently put major efforts into negotiating readmission agreements with transit countries in geographic proximity as well as with more distant countries of origin. This endeavour stands for the Union's attempt to create concentric circles of demarcation and seeks to both extend the redistributive system for the examination of asylum claims to non-EU countries and expulse illegal immigration to outside territory. Such a policy is thus intended to transfer responsibility to non-Member States. The pre-embarkation checks are geographically the outermost and the Schengen border is the innermost. The network of readmission agreements then constitutes the middle circle. The following subsection introduces readmission in more detail.

\subsection{The Instrument of Readmission}

Readmission concerns three actors: the state that requests readmission, the state that is requested to readmit, and the person to be readmitted (either illegal migrant or rejected asylum seeker). Their interests are very different. While the first two actors decide upon the legal framework of readmission, the third one is its mere object. The returning state may refer to the integrity of the asylum system or the migration control system and, for instance, argues that the electorate is in favour of a restrictive control approach. The state requested to readmit may have economic, demographic or social interests in not readmitting its own citizens and, even more so third country nationals. The authorities of the country of origin or transit might show an uncooperative attitude in form of denying that the individual actually possesses their nationality, not issuing the necessary travel documents or objecting modalities of return. The person to be readmitted is confronted with the choice between staying in illegality or returning. If the individual is unwilling to return, the returning state might react by threatening and then also implementing forced removal. ${ }^{12}$

\footnotetext{
${ }^{10}$ Cf. Council of the European Union 2004c.

11 Cf. Council of the European Union 2004a.

12 On the more detailed legal implications of the state's right to expel individuals, see Noll 1999: 24-30.
} 
The instrument of readmission as such is not new. Already the 1851 Treaty of Gotha contained a readmission obligation relating to the signatories' own or former nationals but not to third country nationals. ${ }^{13}$ During the 1990 s the policy instrument gained increasing importance and its scope was extended. Since 1993, the number of bilateral readmission agreements targeting the removal of illegal migrants and unsuccessful asylum seekers has increased significantly. At the end of 1999, 130 readmission agreements were in force between the 15 EU Member States plus Iceland and Norway on the one hand and 58 third countries on the other hand. ${ }^{14}$

The first multilateral readmission agreement was signed between the Schengen states and Poland in 1991. In November 1994 the Council drafted a standard travel document for the expulsion of third-country nationals ${ }^{15}$ and made a recommendation on specimen bilateral readmission agreements between one EC Member State and third countries. ${ }^{16}$ In 1998 the Austrian Presidency submitted a draft readmission agreement between the whole group of EC Member States and third countries, ${ }^{17}$ and called for an EU policy of conditionality in the field of migration:

"An integrated approach must be followed, to the extent that just about all the EU's bilateral agreements with third States must incorporate the migration aspect. For instance, economic aid will have to be made dependent on visa questions, greater border-crossing facility on guarantees of readmission, air connections on bordercontrol standards, and willingness to provide economic co-operation on effective measures to reduce push factors" (Council of the European Union 1998b).

In 1999, the Amsterdam Treaty transferred the competence to negotiate and conclude such readmission agreements with third countries to the European Community. ${ }^{18}$ According to the comprehensive plan to combat illegal immigration and trafficking in human beings, the European Council had to adopt criteria for the identification of third countries with which multilateral readmission agreements should be negotiated. ${ }^{19}$ The EU presidency drafted a proposal on these criteria which had to be examined by the Expulsion Working Party and by the Strategic Committee on Immigration, Frontiers and Asylum (SCIFA); then the Member States' delegations recorded agreement on the text. In the end, the following criteria were adopted: nature and size of migratory flows

\footnotetext{
13 See the Final Protocol of the "Vertrag mit Bayern über den Beitritt zur Deutschen Verfassung" of November 23, 1870; http://verfassungen.de/de/de67-18/bundesvertrag-bayern.htm.

14 Additionally, 14 agreements were signed but are still not in force, 29 were under negotiation and in 26 cases states had contacted each other to prepare for negotiation, see Council of the European Union 1999b. On the recent spread of readmission agreements see in more detail Morrison/Crosland 2001; Jileva 2002; Melis 2001.

${ }^{15}$ Cf. Council of the European Union 1994b.

${ }^{16} \mathrm{Cf}$. Council of the European Union 1994a. In reaction to the specimen bilateral agreement, the Budapest Group on behalf of the central and eastern European countries proposed a concurrent pattern of bilateral readmission agreement, commonly known as the draft Skeleton, in 1995; cf. Budapest Group 1995. In contrast to the EU specimen, the draft Skeleton does not consider stateless persons as nationals but as foreigners. The draft Skeleton rejects the readmission of third country nationals in cases where contracting states do not share common borders.

17 Cf. Council of the European Union 1998a.

18 Title IV, Art. 63 (3) b TEC.

19 Cf. Council of the European Union 2002d.
} 
towards the EU (migration pressure, number of persons awaiting return); geographical position vis-à-vis the EU and regional balance; need for capacity building concerning migration management; existing framework for co-operation; and attitude towards cooperation on migration issues. ${ }^{20}$

Already before the Council drafted the criteria, the Commission received most of the negotiation mandates: in September 2000 for negotiations with Morocco, Sri Lanka, Russia and Pakistan, in May 2001 for Hong Kong and Macao, and in June 2002 for Ukraine. In November 2002, the Commission also received mandates for negotiations with for Albania, Algeria, Turkey and China. ${ }^{21}$ Negotiations have started in 2001, and while agreements with Hong Kong, Macao, Sri Lanka and Albania - and most recently also Russia - have been concluded, the other negotiations are still ongoing or are only about to start.

\subsection{Legitimacy of Readmission}

In general, we have to distinguish between the international obligation to readmit one's own national and the right of an individual to return home. Obligations to readmit are not dependent upon the willingness of the individual to return:

"The right to return does not constitute the right of the individual to choose not to return to his home state if the state of residence withdraws the right of residence" (Hailbronner 1997: 45).

Because of a consistent state practice, today the principle of readmission of a state's own national is accepted as a principle of customary international law. One could even argue that this might probably also be true for third country nationals who have legally resided in another country for a longer period. Here the duration of stay might indicate an obligation to readmit the person in question. ${ }^{22}$

After the Amsterdam Treaty transferred competencies for readmission to the EC, Member States decided to sign only those Community readmission agreements that provide for the return of not only citizens of contracting states but also third country nationals. An obligation to readmit third country nationals, however, cannot be deduced from international law. ${ }^{23}$ Nevertheless, some advocates of the readmission of third country nationals refer to "the principle of neighbourliness and the responsibility of a state for those impairments to other states emanating from its territory" (Hailbronner 1997: 31). They argue that the ideas of good neighbourhood and European solidarity imply that each state bears the responsibility for aliens who have transited their country on their way to a neighbouring state.

What is basically missing for integrating the obligation to readmit third country nationals into customary international law is consistent state practice - and this is what EU Member States are exactly eager for. By establishing a trend towards such an obligation and by including precise descriptions of material and procedural demands on

\footnotetext{
20 Cf. Council of the European Union 2002c.

21 Cf. Council of the European Union 2002a.

${ }^{22}$ Cf. Council of the European Union 1999c; Council of the European Union 1999a.

${ }^{23}$ Cf. Council of the European Union 1999c: 2; Hailbronner 1997: 33-34.
} 
transit countries, the EU is seeking to transform international law. When a new norm is finally established, it will be integrated into customary international law.

Community readmission agreements are being signed on the basis of reciprocity, which means that all contracting states must be prepared to readmit people on the same terms. However, in case of readmission agreements between the EU on the one hand and non-EU Member States on the other, the argument of reciprocity is hypocritical because those countries with which it is of interest for the EU to conclude agreements will not have any problems with expulsions to the EU. It is simply hard to imagine many EU citizens illegally residing in neighbouring countries like Albania or Ukraine. In addition, it does not seem very likely that a third country national who illegally resides in Russia or Albania has previously transited an EU Member State. Accordingly, a member of the Commission's Directorate General for Justice and Home Affairs commented on reciprocity: "Although drawn up on a theoretically reciprocal basis, it is clear that, in practice, readmission agreements largely work in the interest of the Community" (Schieffer 2003: 356). This remark poses the question of how EU Member States and EU institutions justify their efforts to sign comprehensive readmission agreements with transit and sending countries. ${ }^{24}$

When arguing in favour of readmission, EU Member States traditionally point to the principle of national sovereignty, which includes the state's right to decide who is allowed to stay in the country. A state's personal sovereignty is twofold: on the one hand a state is obliged to readmit its nationals expelled from abroad, but on the other hand the obligation to readmit its own nationals derives from the right of the state of residence to expel aliens. EU Member States repeatedly emphasise the importance of enforcing a decision of the immigration authorities to refuse an alien the right to stay for sake of credibility of sovereignty. They further point to their responsibility to protect the international refugee system:

"An agreement can be seen as part of the protection of asylum law and the efforts to prevent misuse of the asylum institute; the agreement may be of symbolic value as it underlines that decisions of return will actually be enforced" (Council of the European Union 1999a: 12).

According to this argument, the EU's credibility depends on the capacity of authorities to effectively refuse an alien the right to stay on in the territory and to successfully enforce such a decision so that the alien in question can be returned to her home country. The Commission further alluded to the implications of failed return for integration policies since massive illegal immigration might result in the failure to improve the social situation of the rest of the immigrant population.

EU actors have increasingly become aware of the difficulties in negotiating readmission agreements with transit countries and of the problematic consequences that readmission agreements entail for them. Accordingly, EU documents have started to refer to the responsibility of each nation state to control its borders efficiently in order to justify EU policy: "The objective of readmission is to make the Member States and third States take responsibility for the failings of their border control systems" (Council

${ }^{24}$ The Council had already pointed to this kind of asymmetrical reciprocity already at an early point in time; cf. Council of the European Union 1999c. 
of the European Union 2001: 9). ${ }^{25}$ It has been argued that readmission agreements function as stimuli for more stringent border control in the transit country.

Representatives of EU countries further argue that readmission policies are legitimate because the agreements must comply with the 1951 Geneva Refugee Convention and the 1967 Protocol on the Status of Refugees, with internal treaties concerning extradition, transit, readmission and asylum and the European Human Rights Convention. According to this argument, readmission agreements only arrange for technical procedures in case of readmission without transferring the executive function from the Member States to the EU:

"As far as the expulsion of illegal migrants is concerned, it is the responsibility of each Member State to ensure that expulsions are carried out in accordance with its obligations arising from the Geneva Convention of 28 July 1951 and the Protocol of 31 January 1967 relating to the status of refugees and other relevant treaties" (Council of the European Union 2000a: 3).

Even though very much discussed on European level, it is not publicly discussed at all that the EU's legitimacy creates what could be conceived of as concentric circles around its own borders by means of readmission agreements which oblige transit countries to readmit not only their own but even third country nationals. We hardly find any media reports on Community readmission agreements.

The readmission of illegal migrants creates severe difficulties for countries of origin or transit mainly because they lack institutions for effective border control, a functioning visa system, the set-up of an asylum system according to the Geneva Refugee Convention and the readmission of third country nationals to their home countries. These countries' political capacity to act is generally limited by non-existent migratory policy institutions so that there is the risk to readmit migrants and asylum seekers to transit countries that have not yet developed adequate safeguards. In the following, the EU readmission agreement with Albania is taken as an empirical example to analyse these challenges in more detail.

\section{Readmission Negotiations between the EU and Albania}

After 44 years of totalitarian communist regime, in 1991 Albania cut her path to political pluralism and a multiparty system. Today political life is of a volatile and confrontational character, and is dominated by strong bipolarisation between the Democratic and the Socialist Parties. During the past few years, intra-party and inter-party struggles repeatedly affected government stability and hampered political reform. The two major problems are corruption and unstable public order. Albania is one of the poorest countries in Europe with substantial parts of its population living under the poverty line, and the economy is informal to a considerable extent. It is both a country of origin and transit, and even today emigration rates are substantial.

\footnotetext{
${ }^{25}$ In a later version, the wording was slightly changed in a more positive way: "Readmission makes the Member States and the third States responsible for controlling their borders efficiently"; cf. Council of the European Union 2002b: 9.
} 
European integration dominates the political agenda as well as the public discussion. In the context of the Stabilisation and Association Process, Albania is a potential candidate for EU accession and has an indisputable, long-term membership perceptive. ${ }^{26}$ In 2003 the EU started negotiations on a Stabilisation and Association Agreement (SAA) with the Albanian government. A future SAA will require Albania to co-operate in the fields of asylum, legal and illegal migration, the control of external borders, visas, and readmission. Between 2000 and 2004, Albania has benefited from around $€ 238.5$ million in CARDS assistance. ${ }^{27}$ In 2003, $€ 20$ million were allocated specifically to actions in the areas of Justice and Home Affairs, ${ }^{28}$ and the CARDS Regional Programme allocated $€ 1$ million in 2002 and 2003 each for integrated border management.

To date Albania has several bilateral readmission agreements in place: with Italy (1997), Switzerland (2000), Hungary (2001), Belgium (2001), Bulgaria (2002), Romania (2002), Germany (2002), and Croatia (2003). Only the Albanian-Italian readmission agreement covers third country nationals. The UK agreement was signed in October 2003 but has not yet been ratified. Negotiations are on-going with the Netherlands, Luxembourg, Macedonia, Slovenia, Slovakia as well as Bosnia and Herzegovina. Albania is also trying to negotiate readmission agreements with Moldova, Ukraine and Turkey but negotiations have not yet started..$^{29}$ The government reports difficulties in starting negotiations on readmission agreements with several countries of origin and some neighbouring countries.

In 1999, Austria stressed that there was no compelling urgency for a readmission agreement with Albania, and nine Member States stated that they had not experienced any difficulties in returning individuals to Albania. Moreover, Italy favoured agreements with Albania on a bilateral level. ${ }^{30}$ Nevertheless, in November 2002 the European Council authorised the European Commission to negotiate a Community readmission agreement with Albania. In March 2003, the Commission submitted the first draft text to the Albania authorities. Negotiations started in May. The second round, which had been scheduled for July, was delayed until September at Albania's request. The third round took place in Tirana on November 6, and the following day the European Commission announced the successful conclusion of negotiations with Albania. The agreement, which was signed in April 2005, is the first of its kind with another European country and overall the fourth that the European Commission has successfully negotiated - after those with Hong Kong, Macao, and Sri Lanka.

In accordance with the high importance of close relations to the EU, the Albanian administration established a separate Ministry of European Integration in 2004. The Ministry's main task is to interact with EU institutions and to co-ordinate negotiations with the Union. The Albanian delegation in the readmission negotiations with the EU was led by the Deputy Prime Minister and Minister of State for European Integration. Further involved were the Ministries of Justice, Public Order, Labour and Social Affairs as well as Foreign Affairs.

\footnotetext{
26 See e.g. Council of the European Union 2000b: paragraph 67.

27 "Community Assistance for Reconstruction, Democratization and Stabilisation".

${ }^{28}$ Cf. Commission of the European Communities 2001a.

${ }^{29}$ Information given by the Albanian Ministry of European Integration in January 2004.

${ }^{30}$ Cf. Council of the European Union 1999d.
} 
Representatives of the Albanian government described their EU counterparts in negotiations as very skilful and specialised because they have a lot of negotiation experience. At the same time, they reported about their own weaknesses due to a lack of familiarity with issues concerning illegal migration. A representative of the European Commission described the challenge for the Albanian actors as follows:

"It is a new activity for them, all of these articles to create, it is completely new whereas if we look at our own Member States they are used to all this. (...) The message that the Albanians were always been given is, please, don't say yes, yes, yes. Be clear (. .), don't think that you have to sign up everything. (. . .) It is one of their weak areas, they need to be tougher. But on the other hand, there is a political game. If the Prime Minister could say my government has managed to sign the SAA, it is powerful (. . .), it is some of relevance" (personal interview, 19.1.2004, Tirana).

The Albanian parliament has not been involved in readmission negotiations with the EU, but according to the government it has been updated regularly. The Parliamentary Commission on European Integration, however, complained about the government's information policy in the context of both the SAA and the readmission negotiations: "Premier Minister Fatos Nano made the negotiations his personal and secret topic" (personal interview, 16.1.2004, Tirana). The parliamentarian not only complained about the government but also accused the European Commission of not having insisted on involving the parliament but instead negotiating directly with the government. According to him, the readmission agreement has not once been discussed in parliament.

Similarly, in 2002 the European Parliament had expressed its regret at having been neither consulted nor kept informed during readmission negotiations with Hong Kong. ${ }^{31}$ While the Macao agreement was under consideration, the parliament further complained that its opinion with regard to the Hong Kong agreement had not been taken into proper account, "either in terms of the provision of information and involvement or in terms of content" (European Parliament 2004: 8). These complaints of both the Albanian as well as the European Parliament illustrate the procedural aspect of Europeanisation in line with our knowledge of EU Member States: namely, that Europeanisation strengthens executive authorities and rather discount or weakens legislative institutions. Readmission is an issue of executive institutions and is only due approval as completed text at the end of negotiations.

Thus, both the European and the Albanian parliament only have a procedural function. They get importance after the signing of the readmission agreement. In case of Albania, that part of the agreement confirming already existing international law - all regulations related to Albanian nationals - takes effect immediately. In contrast, the chapters concerning third country nationals need ratification by the Albanian parliament. Because the readmission agreement is understood as an obligation within the context of the SAA and because all parties - together with the public - generally agree on Albania's European integration efforts, the ratification by the parliament has always been expected to be beyond question.

\footnotetext{
31 Cf. European Parliament 2002.
} 
One member of the Albanian negotiation delegation commented on the negotiation strategy of his government stating that the Albanian party has not seen the readmission agreement as a profitable element but as an element of the overall integration process with the EU. ${ }^{32}$ Similarly, a European Commission's expert explained that the reason for Albania to negotiate a readmission agreement with the EU so quickly lay in the parallel negotiations of the SAA and the underlying membership perspective which put pressure on the country to co-operate. ${ }^{33}$ Article 80 of the draft SAA entails the obligation for Albania to sign a readmission agreement:

"The Parties will agree to conclude an agreement between Albania and the European Community regulating the specific obligations for Albania and for the Member States of the European Union for readmission, including an obligation for the readmission of nationals of other countries and stateless persons." ${ }^{34}$

Even though Article 80 is entitled "Prevention and control of illegal immigration; readmission", it solely deals with readmission. Only the last sentence invites a future Stabilisation and Association Council to think about other measures than readmission to deal with illegal migration. This demonstrates quite clearly that readmission is the EU's main instrument with regard to illegal migration, in particular transit migration.

Another reason for the Albanian government to co-operate with the EU has been the vague hope for some kind of visa liberalisation. However, in contrast to negotiations between the EU and other transit countries, this issue did not evolve as an individual topic but remained an element in the context of EU membership perspective. The European Commission emphasised the long-term character of the visa issue:

"For us it is a question how the Albanian government will sell this [the readmission agreement]. They sell this with the hope that they will one day become a Member State, with the hope that Albania has to have an economy, a society that it is according to normal standards (...). Because, only through this way Albania will be able progressively one day in years to have in mind not just the accession but to give more visa to them or more multi-entry visa and one day perhaps no visa at all" (personal interview, 15.10.2003, Brussels).

In 2005, the European Parliament proposed to use visa facilitation as a reward for Albania when having implemented the agreement (cf. European Parliament 2005: 7). The fact that the Albanian government did not make visa liberalisation or legal emigration possibilities conditional for signing a readmission agreement with the EU has been sharply - but non-influentially - criticised by the parliamentary opposition:

"Rights of our citizens have completely been ignored. It is the Albanians who pay for the third country nationals who use our country to go to Europe. I think the government has not been prepared in negotiating. We urgently need legal emigration possibilities, our people want to leave legally for economic reasons. And what is

\footnotetext{
32 Written statement, 9.2.2004. This has been mentioned by several experts as the main reason for Albania to sign a readmission agreement with the EU so quickly.

${ }_{33}$ Personal interview, 19.9.2003 and 15.10.2003, Brussels.

34 Draft text for the negotiation of a Stabilisation and Association Agreement between the EU and Albania, 3 February 2003, internal document.
} 
with the status of Albanian emigrants in Europe? Over 60 percent of them stay illegal. We need legal possibilities even seasonal once. This has not been considered. The problem is that this government agrees on everything the EU asks" (personal interview, 16.1.2004, Tirana).

The only difficult issue during negotiations were the articles 3 and 5 of the agreement concerning readmission of third country nationals to which the Albanian side agreed only hesitantly. The Albanian government asked for a five-year transitional period before the readmission of third country nationals will start. The EU Commission did not accept the Albanian request, and in the end both sides agreed upon a two-year transitional period before the EU will start readmitting third country nationals to Albania. This means that the third country clause will come into force in 2007 at the earliest. The readmission obligation concerning third country nationals will not apply if the migrant has only been in airside transit via an international airport in Albania or if the requesting Member State has issued to the migrant a visa or residence authorisation before or after entry into its territory. ${ }^{35}$

In summary, negotiations went extremely smooth so that after three rounds both sides already agreed on the text. The Albanian side did not lodge any far-reaching claims or compensations; the only concession the EU had to make was the two-year transitional period. Albania keeps the hope for deeper integration and visa liberalisation in the future. The problem remains, however, to further readmit third country nationals to their country of origin. Readmitting third country nationals to their home countries is a very costly and administratively challenging task. In the text the EU did not make any promise for financial support for the implementation of the agreement. However, the CARDS Albania Country Strategy Paper 2002-2006 lists measures to implement the EU-Albania readmission agreement as part of a project on "strengthening the capacity of Albania to develop and implement an asylum and migration policy according to international standards". The amount of $€ 2$ million is assigned to the whole project, some portion of which will be used for the implementation of the readmission agreement (cf. Commission of the European Communities 2001a). Furthermore, Albania will receive financial assistance in the context of the AENEAS programme. ${ }^{36}$

Many Albanian interview partners expressed serious concerns about Albania turning into a destination country because it will be extremely difficult to convince countries of origin not only to sign a bilateral readmission agreement but also to put it in practice and to take their own nationals back. However, the government hopes that the more readmission agreements the EU will have signed successfully and thus the bigger the international network of readmission agreements grows, the easier it will

35 Cf. Council of the European Union 2005: article 3(2).

36 The AENEAS programme foresees a five-year indicative budget of $€ 250$ million: $€ 30$ million for 2004, $€ 45$ million for 2005 and 2006 each, €60 million for 2007, and €70 million for 2008. One of five key areas is readmission and sustainable reintegration of returnees in their countries of origin. It intends to stimulate the readiness of third countries to conclude readmission agreements with the EU because it explicitly functions as reward for those countries "actively engaged in preparing or implementing a readmission agreement initialled, signed or concluded with the European Community"; cf. Council of the European Union 2004c: L80/2. 
be for Albania to reach readmission agreements with countries of origin. The following section analyses the consequences of the readmission agreement with the EU for Albania and discusses major challenges the Albanian government now has to address in order to properly implement the agreement and to take a step forward on the country's way to European integration.

\section{Implementing the EU Readmission Agreement in Albania}

The EU-Albanian readmission agreement is the first of its kind signed with a European transit country outside EU borders. This section takes Albania as an example to analyse the consequences of the Community readmission agreement for third countries and addresses the challenging aspects of implementation. It makes clear that these consequences concern generally concern all transit countries the EU is negotiation readmission agreements with. Regarding already existing bilateral readmission agreements, Albania can only refer to a rather low implementation record. The Albanian government, representatives of the European Commission as well as EU Member States and employees of international organisations in Albania consistently explain this fact by pointing to the country's lack of appropriate "institutional capacities and infrastructure". ${ }^{37}$ In the following pages, I seek to shed light upon these deficiencies to get a deeper understanding of the challenges Albania is facing regarding the EU's return policy.

Data on return is scarce. On the one hand, only little reliable EU-wide data exist which differentiate between voluntary and forced return; on the other hand, countries of origin most often lack any information about numbers of returnees. In 2002, the European Commission published the first and only "Annual Report on Asylum and Migration" containing national statistical data on refused entry, apprehension of illegal migrants and removal..$^{38}$ However, the data can only serve as a vague indicator because EU Member States did not agree upon common criteria and definitions, and some of them provided only incomplete information. Therefore, we have to assume that the actual numbers are higher than indicated here.

Unfortunately, the data has not been broken down into rejected asylum seekers and illegal migrants. Furthermore, because no information is given about the countries to which removal was implemented, we have to consider that out of the total an indeterminate number of individuals were simply being re-cycled within the EU, which means they were returned to another EU country from which they had arrived. The total numbers of removed aliens were distributed among Member States as follows:

\footnotetext{
37 See e.g. International Organization for Migration 2004a: 63.

${ }^{38}$ Cf. Commission of the European Communities 2002a.
} 
Total Number of Removed Aliens from EU-15

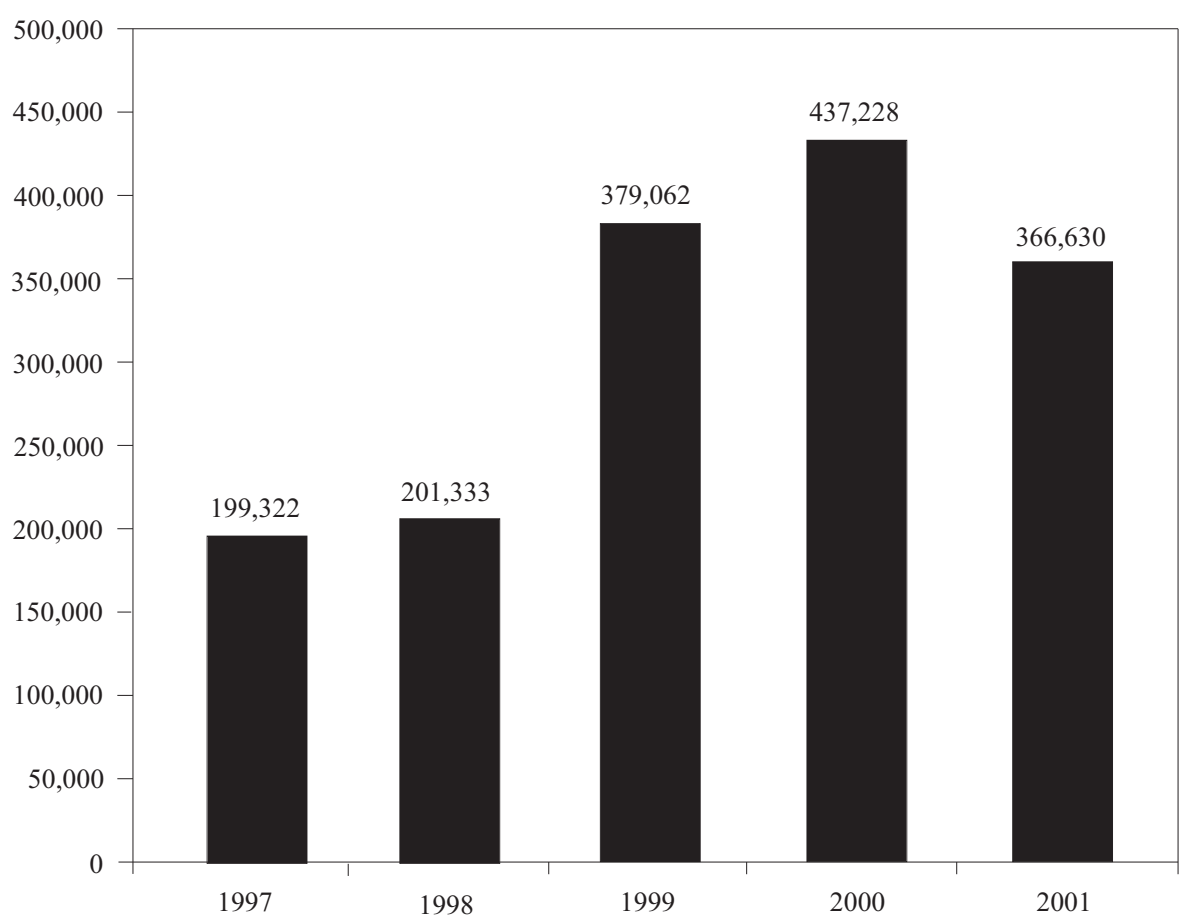

Total Number of Removed Aliens During the Period 1997-2001

\begin{tabular}{|c|c|c|c|c|c|c|}
\hline & 1997 & 1998 & 1999 & 2000 & 2001 & Total \\
\hline Austria & 16,867 & 16,992 & 17,071 & 14,855 & 11,592 & 77,377 \\
\hline Belgium & 4,890 & 3,877 & 3,457 & 4,684 & 8,801 & 25,709 \\
\hline Denmark & & & & 1,339 & 3,056 & 4,395 \\
\hline Germany & 64,869 & 69,989 & 56,539 & 55,813 & 43,950 & 291,160 \\
\hline Greece & & & 184,501 & 225,713 & 167,199 & $\mathbf{5 7 7 , 4 1 3}$ \\
\hline Finland & & & 1,205 & 2,501 & 1,514 & 5,220 \\
\hline France & 9,637 & 7,570 & 7,821 & 9,230 & 8,604 & 42,862 \\
\hline Ireland & & & 6 & 186 & 364 & 556 \\
\hline Italy & 4,700 & 8,950 & 8,978 & 23,955 & 23,836 & 70,419 \\
\hline Luxembourg & & & 64 & 128 & 118 & 310 \\
\hline Netherlands & 39,441 & 36,206 & 36,894 & 25,209 & 16,548 & 154,298 \\
\hline Portugal & & 106 & 906 & 1,143 & 607 & 2,762 \\
\hline Spain & 27,773 & 22,723 & 23,840 & 23,942 & 26,801 & 125,079 \\
\hline Sweden & & & & 1,885 & 4,505 & 6,390 \\
\hline United Kingdom & 31,145 & 34,920 & 37,780 & 46,645 & 49,135 & 199,625 \\
\hline Total & 199,322 & 201,333 & 379,062 & 437,228 & 366,630 & $1,583,575$ \\
\hline
\end{tabular}


For the year 2001, the annual report indicates that Italy returned 8.072 Albanians to Albania. Similarly, Belgium returned 1,010 Albanians and Luxembourg returned 9, so that in 2001 officially a total number of 9,091 Albanians were returned to their home country from EU territory.

Because data is scarce and EU Member States do not provide any data or estimations for the future, the transit countries with which the EC has signed or seeks to sign Community readmission agreements face great difficulties assessing the numbers of returnees - both their own nationals as well as third country nationals - they have to expect from EU Member States after the Community readmission agreement takes effect. This uncertainty creates severe difficulties because authorities are in the dark regarding personnel and administrative capacities required, the extent of reintegration programmes, assistance and job training required, and the scope of detention facilities needed. In addition, it is rather difficult to prioritise with which countries of origin they should begin to negotiate bilateral readmission agreements because they lack experience to help them anticipate which third country nationals EU Member States will readmit to Albania.

\subsection{Return of Albanian Nationals to Albania by EU Member States}

Regarding Albanian nationals, over 300 individuals voluntarily returned to Albania between 2000 and 2004 through IOM assisted return programmes. The Albanian National Strategy on Migration foresees information campaigns providing potential voluntary return migrants with information on their status, rights and services offered upon return. This information is to be distributed through diplomatic and consular services as well as through emigrant associations, and assistance of NGOs and international organisations has been requested. The number of forced returns has been much higher than that of voluntary returns: in 2003 alone, more than 30.000 individuals were either readmitted from a state's territory or expelled back to Albania at the borders. According to IOM, the numbers of returns were particularly high in the cases of Italy and Greece where many Albanians live or work illegally and the UK where Albanians were not recognised as refugees. Most Western European countries return Albanian nationals through flights back to Albania; Italy and Greece return them directly over the border or at the ports of Durres and Vlora.

The Albanian body responsible for the overall return process is the Ministry of Public Order. Under its control, the Directorate for Border and Migration (even more exactly, the Sector for Foreigners and Migration) within the General Directorate for Border Police is responsible for the implementation of readmission agreements. ${ }^{39}$ A special unit, which deals exclusively with return issues, will be created, but not until 2007.

Regarding the return of Albanian nationals, the main challenge relates to their reintegration in the country. The European Parliament has asked the EU Member States to provide reintegration assistance for Albanian citizens in order to achieve sustainable return (cf. European Parliament 2005, p. 7). So far no special assistance exists for Albanian nationals upon return - with the exception of vulnerable groups such as

39 Cf. International Organization for Migration 2004a: 62. 
unaccompanied minors and victims of trafficking. These groups are to be identified through a screening mechanism, which all returnees undergo. The Law on Emigration for Employment Purposes generally provides for assistance to returnees in case of voluntary return. Article 13 states:

"The government promotes voluntary return of emigrants in their home country and their economic and social reintegration through the creation of legal, financial and fiscal initiatives, including the implementation of business development, employment and vocational training".

Unfortunately, necessary bi-laws are still missing so that this law has not yet been implemented by the Ministry of Labour and Social Affairs, which is responsible for social protection and reintegration of returnees. In the National Strategy on Migration, the Albanian government stated:

"A Council of Ministers decision needs to specify which categories of voluntary returnees reintegration assistance will be eligible to and what kind of assistance will be provided. Bearing in mind that many categories of returnees are not necessarily voluntary returnees, there is a need to adopt provisions covering other categories of returnees as well" (Albanian Government 2004: 24-25).

In addition, Article 4 (3) of the Law on Consular Functions calls for financial assistance for Albanian returnees upon approval of the Ministry of Foreign Affairs, and even the National Strategy on Employment and Vocational Training mentions the necessity to provide opportunities for vocational training to Albanian returnees with economic and/or social problems. However, even this strategy still awaits implementation.

In view of the EU readmission agreement, IOM has agreed to assist the Albanian government in implementing its readmission policy. In the 18-month project mechanisms to support Albanian returnees rank high. These mechanisms are to be available for both voluntary as well as forced returnees. The Albanian National Employment Service has been asked to participate in developing mechanisms to assist returnees in matching their specific skills with the needs of the labour market in Albania. This project is currently beginning to be implemented in employment offices in Durres, Tirana and Elbasan.

Even though Albania is obliged to take its own nationals back because of international customary law, the return of Albanians to their home country creates major difficulties. According to estimations, today about 20,000 to 40,000 Albanians emigrate illegally every year and an estimated stock of 400,000 Albanians live illegally in foreign countries (cf. Gjonca 2002: 34). Remittances play a major role in Albanian economy: Last year, emigrants sent about $\$ 972$ million back home. This means that many families in Albania simply depend upon money transfer from dependants who work abroad illegally. Return may very well result in the destruction of their economic basis and the deterioration into poverty.

Illegal emigrants most often stem from remote Northern or Southern rural areas, but when being returned these migrants prefer to stay in or around Tirana. As a consequence, their families may leave their villages in the mountains to join their dependants so that the Albanian authorities have to deal with internal migration and rapid urbanisation. Another important implication of return is re-emigration. At least in case 
of forced return, many migrants look for possibilities to go abroad again because they lack an acceptable prospect in their home country. In all these dimensions, the return of its own nationals is a complex issue that brings about a lot of challenges for Albanian authorities.

\subsection{Return of Third Country Nationals to Albania by EU Member States}

Article 11 of the Albanian law of foreigners provides that based on readmission agreements, Albania shall readmit third country nationals expulsed by other states in case in which they demonstrably departed or transited from Albania. Article 47 (3) of the same law states that such foreigners accepted on the basis of readmission agreements can further be expelled to the country of origin or residence.

So far, Albania lacks any experience in returning third country nationals to their home country or another transit country on the basis of existing readmission agreements. According to the Albanian government, as of the end of 2004, there were no recorded cases of return of third country nationals on the basis of readmission agreements with EU Member States. ${ }^{40}$ Instead, return has been taking place through voluntary return programmes assisted by IOM (194 returnees from 2001 to 2004) or with the help of respective embassies. IOM Albania assists in the voluntary return of illegal migrants apprehended by Albanian authorities on the country's territory, of illegal migrants who approach the organisation wishing to return voluntarily, and of rejected asylum seekers. As in the case of Albanian returnees, the government's National Strategy on Migration anticipates information campaigns regarding possibilities for third country nationals to voluntarily return to their home countries and to get assistance in doing so.

Regarding forced return, there is a de-facto agreement with Italy to return transit migrants directly to their home country because of the insufficient Albanian infrastructure. This acknowledges that Albanian authorities have no experience in dealing with the whole detention and return procedure and thus have to be trained in order to provide for compliance with human rights law, refugee law, and international conventions.

Asked which provisions have to be made before the readmission of third country nationals to Albania begins, a representative of the Ministry of Public Order listed the following:

“(i) To complete the domestic legal framework,

(ii) To start establishing the appropriate structures and to specify the directions involved (Ministry of Foreign Affairs, Ministry of Public Order, Ministry of Labour and Social Affairs etc.),

(iii) To prepare the personnel who will deal with readmission,

(iv) Strongly to ask for agreements with third countries". ${ }^{41}$

Because neither the Albanian government nor relevant international organisations nor the EU itself are in a position to reliably predict the potential level of third country

\footnotetext{
${ }^{40}$ Information received by representatives of the Ministry of Public Order and the Ministry of European Integration in personal interviews, November 2004.

41 Written statement, 9.2.2004.
} 
nationals that will be returned to Albania by EU Member States, measures providing for the implementation of the readmission of third country nationals rest upon vague assumptions. The only indicator from which size of flows and main countries of origin can be interfered is the pre-screening system for identification of illegal migrants on Albanian territory. The pre-screening system refers individual foreigners to the responsible authorities according to their profile: asylum seekers are in the jurisdiction of the Directorate for Refugees and UNHCR whereas economic migrants who wish to return to their countries of origin are directed to IOM and victims of trafficking to the OSCE. Between February 2001 and August 2003, 602 foreigners have been pre-screened and referred to the respective systems (cf. Hoffmann 2003). When we additionally consider the numbers of border apprehensions, the main countries of origin are Bangladesh, Belarus, China, Iraq, Iran, Moldova, Serbia, Turkey, and Ukraine.

Like other transit countries, Albanian authorities fear what they call the "readmission trap", a term used to describe the case in which Albania is the only South-eastern European country to sign a readmission agreement with the EU and thus has to readmit many third country nationals who also transited through other countries in the region. ${ }^{42}$ Similar concerns have been expressed by the European Parliament:

"Without corresponding agreements, either between countries of the region, or with countries of origin, there is a risk of creating a readmission trap in which third country nationals find themselves stranded in the region. This inevitably will create pressure for irregular migrants to make their way back to the EU" (European Parliament 2005: 7).

Therefore, one high priority goal is the conclusion of bilateral readmission agreements with neighbouring countries, other transit states and countries of origin. On several occasions, Albania has asked the EU to provide support in convincing neighbouring countries as well as countries of origin to begin and complete negotiations. However, the EU's commitment to positively engage in influencing these negotiations is limited. ${ }^{43}$ An IOM project, which began in December 2004, is intended to address the Albanian capacity to negotiate and implement readmission agreements with third countries. The main focus lies on improving the knowledge and expertise of Albanian counterparts in readmission negotiations. Therefore, a model readmission agreement is currently being created and a Readmission Implementation Reference Handbook is to be written in the near future. ${ }^{44}$ Further envisaged are training for authorities involved in negotiation and implementation of readmission agreements such as language training, workshops and study visits to share best practices and experience.

Albania seeks to approach countries of origin to provide for facilitating procedures for receiving necessary travel documents in the context of readmission. Contacts were established with foreign embassies in Albania and by Albanian consulates abroad. Furthermore, to prevent having third country nationals disappear on Albanian territory, the Ministry of Public Order is asked to create a tracking system to ascertain the movements of third country national returnees.

42 Cf. Albanian Government 2004: 26.

43 Information given by a Commission representative in a personal interview, 15.10.2003, Brussels.

44 According to IOM Albania, both the model readmission agreement and the readmission implementation reference handbook should be drafted by mid March 2006. 
Detention facilities for third country nationals awaiting further removal need to be established. The Ministry of Public Order currently is in the preparation phase for the creation of a closed reception centre for repatriated third country nationals. According to IOM, the decision about the location of this centre has not yet been made, and the size of the facility is still under discussion. A delegation of the Albanian government visited a closed reception facility in an EU Member State last year to get information about common standards related to facilities for women or families, medical and social care, and security.

Currently, illegal migrants apprehended on Albanian territory are received at socalled reception screening facilities throughout the country. ${ }^{45}$ This is where the police screen the migrants even before referring them to the pre-screening team. After that, victims of trafficking irrespective of their nationality as well as illegal migrants expressing their wish to return home are all accommodated at the National Reception Centre for Victims of Trafficking run by IOM. There is a separate facility for asylum seekers and refugees near Tirana but no accommodations exist for returned third country nationals awaiting their readmission.

The Law on Foreigners generally regulates aspects of removal and the Law on the Guard and Control of the State Border provides the legal basis for the reception and the detention of illegal migrants but necessary bi-laws on expulsion procedures and detention must be adopted before 2007. A first legal basis for establishing reception centres has been adopted in February 2002 through the approval of the "Regulation on the Functioning of the Centres of Reception and Temporary Treatment of the Foreigners who are not Asylum Seekers". ${ }^{46}$ The General Directorate of the Border Police will be responsible for running the detention centres.

In summary, the readmission of third country nationals to Albania poses a great challenge for the Albanian government. The institutional infrastructure of Albanian authorities is insufficiently developed and the personnel lack any experience in carrying out the various steps of the return procedure. Proper communication among various organisational units is not provided for, the technical equipment is insufficient and the staff is untrained regarding human rights aspects of the situation and respect for migrants and their needs. Facilities for adequate lodging and accommodation are non-existent, and the return of migrants to their home countries is nearly impossible given the administrative, organisational, and financial implications of readmission. Therefore, Albania risks being left with substantial numbers of aliens who might pose a social and economic burden for the country by turning it into a country of destination.

\subsection{Possible Implications for the Albanian Asylum System}

Readmission agreements not only provide for the return of illegal migrants but also for that of rejected asylum seekers. The return of rejected asylum seekers has gained particular importance during the 1990s when more and more Western European countries introduced the so-called "safe third country" notion. Even the Dublin Convention,

\footnotetext{
45 These facilities are located at Rinas Airport, Tirana, Gjrokaster, Vlora, Peshkopia, Shkodra, Elbasan, Kukes, and Korca.

${ }^{46}$ Cf. Council of Ministers decision no. 46.
} 
which determines the Member State responsible for examining applications for asylum, allows governments to shift responsibility for examining an asylum claim to a non-EU Member State. Asylum seekers who have passed through a third country in which they could have found protection are returned to this state without examination of their asylum claim. ${ }^{47}$ To implement the notion of "safe third country", EU Member States signed several bilateral or multilateral readmission agreements with neighbouring countries. Even though governments of Member States argued that the "safe third country" notion is meant to stop the so-called "asylum shopping", in fact this practice simply prevents most asylum seekers from filing their asylum claims in the EU.

No rule exists saying that asylum seekers are obliged to file a claim in the first country possible. But sending an asylum seeker to another state where no persecution is feared is also not explicitly forbidden by international law - and that is exactly what readmission agreements are about. According to the Geneva Refugee Convention and its principle of non-refoulement, receiving states are obliged to examine the claim before returning the applicant to a third country, to verify that the individual applicant will really be safe. However, cases of expulsion without prior examination of the claim are very common, and in many cases return procedures are rather informal and the returning state merely informs the receiving country of the planned return (cf. Landgren 1999: 26). The majority of bilateral readmission agreements between EU Member States and third countries do not contain any explicit reference to the principle of nonrefoulement. ${ }^{48}$ Even though the notion of "safe third countries" requires that these countries have signed international agreements, most importantly the Geneva Refugee Convention and the European Convention for the Protection of Human Rights and Fundamental Freedoms, their proper implementation is not considered. Readmission agreements do not explicitly oblige the "safe third country" to assure asylum seekers access to a fair refugee determination procedure in line with international standards. In addition, returning states might not even make clear that the individual is an asylum seeker who was refused only on formal grounds of the "safe third country" rule.

Chain deportation might be the consequence, but information about the handling of returnees is rare:

"Astonishingly not a single public report is available on what happens to migrants when they arrive wherever they are taken. It appears that the EU collectively feels no responsibility for the lives and welfare of people it expels" (Statewatch 2002).

UNHCR formulated basic rules to be respected when readmitting an asylum seeker to a third country on the basis of the "safe third country" notion.

"(i) the circumstance that the asylum-seeker has been in a third State where he could have sought asylum does not, in and by itself, provide sufficient grounds for the State in whose jurisdiction the claim has been submitted to refuse

\footnotetext{
${ }^{47}$ It is important to differentiate the "safe third country" from the "first country of asylum": "A "first country of asylum' is a country where a person has already been granted some legal status allowing him/her to remain in the territory either as an asylum seeker or as a refugee, with all the guarantees which international standards attach to such status. A country where the person could have found protection is not a first country of asylum in this sense"; cf. UNHCR 2001a.

${ }^{48}$ Cf. UNHCR 2001b; Rogers/Peers 2005.
} 
considering his/her asylum request in substance and return him/her instead to the third country;

(ii) the transfer from one State to another of the responsibility for considering an asylum request may only be justified in cases where the applicant has meaningful links or connections (e.g. family or cultural ties, or legal residence) with that other State; and

(iii) when effecting such a transfer there must be, in each individual case, sufficient guarantees that the person will be readmitted to that country, enjoy effective protection against refoulement, have the possibility to seek and enjoy asylum, and be treated in accordance with accepted international standards" (UNHCR 2001a).

Generally, mere transit through a third country does not constitute such a meaningful link. This point, however, is most often not considered by returning states.

In 2004, the UNHCR office in Albania commissioned a study to determine whether or not Albania fulfils the criteria of a "safe third country". The results are unambiguous: it does not. Even though Albania introduced legal provisions in line with international standards and for the first time created an asylum system including a refugee status determination procedure, much has to be done in practical terms to implement the laws:

"The fact that the third country in question has ratified the Refugee Convention and its Protocol and purports to have a functioning asylum system is simply not enough to ensure that a person returned on the basis of the safe third country concept would in reality have access to effective and durable protection in the third country. Neither does ratification of applicable treaties and creation of comprehensive domestic laws guarantee that the asylum procedure fulfils international refugee standards for a fair and efficient asylum determination procedure, including viable protection and reception options throughout the procedure" (Chadbourne 2004: 9).

UNHCR in Albania is concerned about refused entry to persons at borders and harshly complains about non-transparent and insufficient asylum procedures. Timeframes are not respected, no regular meetings for the refugee status determination exist, the responsible Directorate of Refugees does not properly inform applicants during the procedure, no provisions have been made for most vulnerable groups, and the quality of information on countries of origin is seriously low. Furthermore, an effective appeal opportunity is still lacking. Up to now the National Commission for Refugees has not been constituted completely, an internal regulation on the appeal process has not been drafted thus far and the information given to the Commission for its decision on the appeal are one-sided and only reflect the government's position. Reception conditions are inadequate, and sustainable local integration of refugees remains unattainable.

The moment the readmission of third country nationals from the EU to Albania begins, this very weak Albanian asylum system might be put at risk. If EU Member States make quite extensive use of the possibility of readmitting third country nationals to Albania, and if substantial numbers of these apply for asylum in the country, the system might soon be overstrained. Right now the number of asylum seekers is very low: in 2003 some 50 cases. Nevertheless, the Albanian government has severe difficulties adhering to time limits, providing services of interpreters, promptly communicating 
with applicants and running a shelter for asylum seekers. These difficulties will get even worse when the number of applications rises. Furthermore, sustainable local integration of refugees is very difficult, especially because of the disastrous economic situation in the country. This will put the question of resettlement in Western European countries back on the table. In view of the low quality of the Albanian asylum system and the country's very poor economic performance, the EU cannot close her eyes to the consequences that extensive return of rejected asylum seekers to Albania would have. Moreover, not only rejected asylum seekers but also illegal migrants can apply for asylum upon return to Albania. UNHCR Albania assumes that substantial numbers of illegal migrants might have a severe claim for protection.

At the same time, the fact that Albania is not a "safe third country" of asylum according to UNHCR criteria indicates that the return of rejected asylum seekers to Albania might imply a lowering of asylum standards below internationally accepted standards. The rights of asylum seekers to have a minimum quality of living conditions during the procedure, to get necessary information, to have a transparent and fair procedure, and to have access to an independent appeal process might be violated on the part of EU Member States.

\section{Conclusion}

Negotiating Community readmission agreements with transit countries in geographic proximity that include regulations for citizens of contracting states as well as third country nationals has been a prime EU activity in the area of illegal migration since the turn of the millennium - but it turned out to be a very difficult task. In this policy area, the EU is very much dependent upon the co-operation of third countries since otherwise EU policies on border control, immigration restriction or visa regulations will remain insufficient. Although all non-Member States at hand at the end agreed to start negotiations, they reacted differently to the EU's attempt to influence their domestic politics.

In case of Albania, negotiations preceded very smoothly. Already after three rounds of negotiations both sides agreed on the text. The Albanian side did not lodge any farreaching claims or compensations. In the context of the SAA, Albanian authorities took the readmission agreement as just one out of many obligations to meet. The only demand from the Albanian side was a transitional period before starting the readmission of third country nationals, and both partners agreed on a compromise of two years. The driving mechanism behind Albania's willingness to co-operate was the country's membership perspective. By making readmission conditional in the context of the SAA, the EU indirectly linked readmission with membership. Even though the Albanian perspective for EU membership is very long-term, in principle it is undisputed and guaranteed in writing, and the rules of the game are clear - different to that of, e.g., Turkey or Ukraine.

The Albanian government did not face major opposition to a readmission agreement with the EU on domestic level. The Albanian parliament had not been involved at all into negotiations and its institutional role is generally rather weak. Thus, in the procedural dimension, the external effects of Europeanisation resulted in strengthening the 
executive authorities in Albania - which corresponds to our knowledge on the effects of Europeanisation in EU Member States. Even though the parliamentary opposition complained about being ignored, the government had no reason to fear that the opposition will respond by blocking the ratification of the agreement. The overall goal of close relations with the EU and progress in integration prohibited far-reaching opposition. The same holds true for the public: Since opposition against European integration is basically non-existent even in the population, the negotiations on readmission did not meet any public criticism at all. According to the European Parliament (2005: p. 7), the provisions of the agreement are little known both within state entities responsible for its implementation and by the public at large and by civil society.

In the material dimension of Europeanisation, however, the readmission agreement has major consequences for Albania that are very difficult to deal with. On a general basis, the readmission procedure requires an administrative infrastructure, established communication channels among various implementing bodies, sufficient human resources and trained personnel. The readmission of Albanian nationals is anchored in international law and is beyond dispute. Nevertheless, returnees constitute a major challenge for both the Albanian authorities and the society because their reintegration is very difficult but crucial. Because of the very weak economy and a high unemployment rate, returnees often face major difficulties in earning their own living - and that of their families who most often are relying upon remittances of the dependant abroad. At the same time, the government's financial capacities to provide a better reintegration structure are very limited. In the end, substantial numbers of returnees - at least if they were forced to return - may decide to go abroad again which would mean that readmission is not sustainable at all.

The EU-Albanian readmission agreement also provides for the return of third country nationals who transited Albania on their way to the EU. The readmission of third country nationals is not regulated by international law. Instead, the EU seeks to create a new international norm or a consistent state practice by concluding more and more readmission agreements that also apply to third country nationals. Whether or not this is legitimate has only rarely been discussed. The Union is dependent upon the co-operation of transit countries and has little to offer because these readmission agreements only work in the interest of the EU. Transit countries have countered with conditionality demands. As described above, in the case of Albania, the membership perspective has sufficed as an incentive. However, readmission of third country nationals is extremely challenging for Albania. An accommodation infrastructure for third country nationals awaiting return to their home countries is non-existent and the staff is untrained in dealing with illegal migrants and rejected asylum seekers and in respecting their basic human rights. Furthermore, readmission agreements with neighbouring transit countries and countries of origin have not yet been concluded and are very difficult to negotiate. Thus, Albania runs the risk of turning into a country of destination - a challenge the country cannot cope with economically, socially and politically. In addition, the Albanian asylum system might be put at risk when substantial numbers of readmitted third country nationals apply for asylum in Albania. This will probably result in lowering of asylum standards below internationally agreed standards.

Albania faces great difficulties in assessing the numbers of returnees she has to expect by EU Member States in the future. This uncertainty leaves authorities in the 
dark with regard to needed personnel and administrative capacities, the necessary extend of reintegration programmes, assistance and job training, and the required size of detention facilities. At the same time, it is not only unclear how many illegal migrants and rejected asylum seekers EU members states intend to readmit but even how many they really can readmit at the end for two reasons. First, if Albania's limited capacities are exhausted it might not be in the interest of the EU anymore to keep on readmitting people. Second, it is difficult to assess in how many cases Member States' authorities have the ability to unambiguously identify the individual's nationality or to provide sufficient proof for migration routes. Thus, the success of common return policies seems to be rather questionable. And even in case of exemplary implementation of the EUAlbanian readmission agreement, an important question - probably also numerically remains for the EU: how to deal with illegal migrants whose nationality cannot be identified with sufficient certainty.

\section{References}

Albanian Government, National Strategy on Migration. Tirana: Albanian Government, 2004. http://iomtirana.org.al/Arkiva/Final\%20engversion\%20\%20aproved\%20by\%20CM-\%2019.11.2004.doc

Bruggeman, W., Illegal Immigration and Trafficking in Human Beings Seen as a Security Problem for Europe. Brussels: Deputy Director Europol, 2002.

Budapest Group, Report of the Expert Group (prepared by the Czech Republic) on the Implementation of Readmission Agreements. Paper presented at conference on Third International Conference of the Budapest Group, Zurich, 14-15 September 1995.

Chadbourne, Julie, Meeting the Mark: Asylum in Albania and the Safe Third Country Concept. Tirana: UNHCR, 2004.

Cholewinski, Ryszard, The EU Aquis on Irregular Migration: Reinforcing Security at the Expense of Rights. In: 2000 European Journal of Migration and Law 2, 361-405. http://www.kluweronline.com/issn/1388-364X

Commission of the European Communities, Communiation from the Commission to the Council and the European Parliament on Immigration and Asylum Policies. COM (1994) 23 final. Brussels: European Commission, 1994.

Commission of the European Communities, European Community CARDS Programme. Albania Country Strategy Paper 2002-2006. Brussels: European Commission, 2001a.

http://europa.eu.int/comm/external relations/see/albania/csp/02 06 en.pdf

Commission of the European Communities, Proposal for a Council Directive on the Conditions of Entry and Residence of Third-country Nationals for the Purpose of Paid Employment and Self-employed Economic Activities. COM (2001) 386 final. Brussels: European Commission, 2001b.

http://europa.eu.int/eurlex/lex/LexUriServ/site/en/com/2001/com2001_0386en01.pdf

Commission of the European Communities, Annual Report on Asylum and Migration (2001). Brussels: European Commission, 2002a.

http://europa.eu.int/comm/justice_home/doc_centre/asylum/statistical/doc_annual_report_2001_en.htm

Commission of the European Communities, Communication from the Commission to the Council and the European Parliament: Integrating Migration Issues in the European Union's Relations with Third Countries. COM (2002) 703 final. Brussels: European Commission, 2002b.

http://europa.eu.int/eur-lex/en/com/cnc/2002/com2002_0703en01.pdf

Commission of the European Communities, Green Paper on a Community Return Policy on Illegal Residents. COM (2002) 175 final. Brussels: European Commission, 2002c.

http://europa.eu.int/eur-lex/en/com/gpr/2002/com2002_0175en01.pdf

Commission of the European Communities, Commission Staff Working Paper: Annual Report on the Development of a Common Policy on Illegal Immigration, Smuggling and Trafficking of Human Beings, External Borders, and the Return of Illegal Residents. SEC (2004) 1349. Brussels: European Commission, 2004. http://europa.eu.int/comm/justice_home/doc_centre/immigration/illegal/doc/sec_2004_1349_en.pdf 
Council of the European Union, Council Recommendation Concerning a Specimen Bilateral Readmission Agreement Between a Member State and a Third Country. Official Journal C 274, 19/09/1996, 0020 0024. Brussels: European Council, 1994a. http://europa.eu.int/eurlex/lex/LexUriServ/LexUriServ.do?uri=CELEX:31996Y0919(07):EN:HTML

Council of the European Union, Council Recommendation Concerning the Adoption of a Standard Travel Document for the Expulsion of Third-Country Nationals. Official Journal C 274, 19/09/1996, pp. 0018-0019. Brussels: European Council, 1994b.

http://europa.eu.int/smartapi/cgi/sga_doc?smartapi!celexapi!prod!CELEXnumdoc\&lg=EN\&num doc $=31996$ Y0919(06)\&model=guichett

Council of the European Union, Draft Readmission Agreement between the EU Member States, of the One Part, and Third Countries, of the Other Part. 10338/1/1998. Brussels: European Council, 1998a.

Council of the European Union, Strategy Paper on Immigration and Asylum Policy. 9809/98. Brussels: European Council, 1998b. http://www.proasyl.de/texte/europe/eu-a-o.htm

Council of the European Union, Analysis of the Institute Concerning Readmission Agreements. 7707/99. Brussels: European Council, 1999a. http://register.consilium.eu.int/pdf/en/99/st07/07707en9.pdf

Council of the European Union, Inventory of Readmission Agreements. 11486/99. Brussels: European Council, 1999b. http://register.consilium.eu.int/pdf/en/99/st11/11486en9.pdf

Council of the European Union, Readmission Agreements Concerning Third-Country Nationals. 7669/99. Brussels: European Council, 1999c. http://register.consilium.eu.int/pdf/en/99/st07/07669en9.pdf

Council of the European Union, Summary Report of Member States' Contributions on Readmission Questions. 7609/1/99. Brussels: European Council, 1999d. http://register.consilium.eu.int/pdf/en/99/st07/07609-r1en9.pdf

Council of the European Union, Readmission Clauses. 5472/00. Brussels: European Council, 2000a. http:// register.consilium.eu.int/pdf/en/00/st05/05472en0.pdf

Council of the European Union, Santa Maria Da Feira European Council Presidency Conclusions. Brussels: European Council, 2000b.

http://ue.eu.int/ueDocs/cms_Data/docs/pressData/en/ec/00200-r1.en0.htm

Council of the European Union, Catalogue of Recommendations for the Proper Application of the Schengen Acquis and of Best Practices - Removal and Readmission. 12790/1/01. Brussels: European Council, 2001. http://register.consilium.eu.int/pdf/en/01/st12/12790-r1en1.pdf

Council of the European Union, Advances Made in Combating Illegal Immigration. 10009/02. Brussels: European Council, 2002a. http://register.consilium.eu.int/pdf/en/02/st10/10009en2.pdf

Council of the European Union, Catalogue of Recommendations for the Correct Application of the Schengen Acquis and of Best Practices - Removal and Readmission. 12790/3/01. Brussels: European Council, 2002b. http://register.consilium.eu.int/pdf/en/01/st12/12790-r3en1.pdf

Council of the European Union, Draft Council Conclusions on Intensified Cooperation on the Management of Migration Flows with Third Countries. 13894/02. Brussels: European Council, 2002c. http://register.consilium.eu.int/pdf/en/02/st13/13894en2.pdf>

Council of the European Union, Proposal for a Comprehensive Plan to Combat Illegal Immigration and Trafficking of Human Beings in the European Union. 2002/C 142/02. Brussels: European Council, $2002 \mathrm{~d}$. http://europa.eu.int/eurlex/pri/en/oj/dat/2002/c_142/c_14220020614en00230036.pdf

Council of the European Union, 2002e: Proposal for a Return Action Programme. 14673/02. Brussels: European Council, 2002e. http://register.consilium.eu.int/pdf/en/02/st14/14673en2.pdf

Council of the European Union, Council Conclusions on Elements for Establishing Preparatory Actions for a Financial Instrument for Return Management in the Area of Migration. 10375/04. Brussels: European Council, 2004a. http://register.consilium.eu.int/pdf/en/04/st10/st10375.en04.pdf

Council of the European Union, Council Decision Providing for Certain Areas Covered by Title IV of Part Three of the Treaty Establishing the European Community to Be Governed by the Procedure Laid Down in Article 152 of that Treaty. 15226/04. Brussels: European Council, 2004b. http://register.consilium.eu.int/pdf/en/04/st15/st15226.en04.pdf

Council of the European Union, Implementing Council Decision on the Shared Organisation of Joint Flights for Removals, from the Territory of Two or More Member States, of Third-Country Nationals who Are the Subject of Individual Removal Orders. 6144/04. Brussels: European Council, 2004c.

http://register.consilium.eu.int/pdf/en/04/st06/st06144.en04.pdf 
Council of the European Union, Council Decision on the Signing of the Agreement Between the European Community and the Republic of Albania on the Readmission of Persons Residing Without Authorisation. 5614/05. Brussels: European Council, 2005. http://register.consilium.eu.int/pdf/en/05/st05/st05614.en05.pdf European Parliament, Report on the Proposal for a Council Decision on the Signing of the Agreement Between the European Community and the Government of the Special Administrative Region of the People's Republic of China on the Readmission of Persons Residing Without Authorisation. A5-0381/2002. Strasbourg: European Parliament, 2002.

http://www2.europarl.eu.int/omk/sipade2?PUBREF=//EP//NONSGML+REPORT+A5-2002-0381+ $0+\mathrm{DOC}+\mathrm{PDF}+\mathrm{V} 0 / / \mathrm{EN} \& \mathrm{~L}=\mathrm{EN} \& \mathrm{LEVEL}=2 \& \mathrm{NAV}=\mathrm{S} \& \mathrm{LSTDOC}=\mathrm{Y}>$

European Parliament, Report on the Proposal for a Council Decision Concerning the Signing of the Agreement between the European Community and the Macao Special Administrative Region of the People's Republic of China on the Readmission of Persons Residing without Authorisation. Final A5-0096/2004. Strasbourg: European Parliament, 2004.

http://www2.europarl.eu.int/registre/seance_pleniere/textes_deposes/rapports/2004_P5/0096/P5 A(2004)0096_EN.pdf>

Gibney, Matthew J., Deportation and the Liberal State: The Forcible Return of Asylum Seekers and Unlawful Migrants in Canada, Germany and the United Kingdom. New Issues in Refugee Research, Working Paper No. 77, Geneva: UNHCR, 2003.

Gjonca, Arjan, Albanische Emigration in den neunziger Jahren - eine neue Ära in der demographischen Entwicklung. In: Karl Kaiser/Robert Pichler/Stephanie Schwandner-Sievers (eds.), Die weite Welt und das Dorf. Albanische Emigration am Ende des 20. Jahrhunderts. Wien et al.: Böhlau, 2002, pp. 15-38.

Guiraudon, Virginie/Gallya Lahav, A Reappraisal of the State Sovereignty Debate. The Case of Migration Control, 2000 Comparative Political Studies 33, pp. 163-195.

Hailbronner, Kay, Readmission Agreements and the Obligation of States under Public International Law to Readmit their Own and Foreign Nationals, 1997 Zeitschrift für ausländisches öffentliches Recht und Völkerrecht 57, pp. 1-50.

Hoffmann, Marion, Managing the Flows. Albania's Three-Pronged Approach. Athens: Human Rights Defence Centre (KEPAD), 2003.

Huysmans, Jef, The European Union and the Securitization of Migration. 2000 Journal of Common Market Studies 38, pp. 751-777.

International Organization for Migration, The Return and Reintegration of Rejected Asylum Seekers and Irregular Migrants. Geneva: IOM, 2001.

International Organization for Migration, Analysis of Albanian Immigration Legislation and Practice as Compared to EU and International Standards. Gap Analysis on Migration Management in Albania. Tirana: IOM, 2004a. http://www.iom.int/en/PDF_Files/tcm/Albania_GAP.pdf

International Organization for Migration, Return Migration. Policies \& Practices in Europe. Geneva: IOM, 2004b.

Jileva, Elena, 'Larger than the European Union: The Emerging EU Migration Regime and Enlargement'. In: Sandra Lavenex/Emek M. Ucarer (eds.), Migration and the Externalities of European Integration. Lanham et al.: Lexington Books, 2002, pp. 75-89.

Koser, Khalid, Return, Readmission and Reintegration: Changing Agendas, Policy Frameworks and Operational Programmes. In: Bimal Gosh (ed.) Return Migration. Journey of Hope or Despair? Geneva: International Organisation for Migration, 2000, pp. 57-99.

Kruse, Imke, EU Readmission Policy and Its Implications for Non-Member States, Berlin: Free University, 2005.

Landgren, Karin, Deflecting International Protection by Treaty: Bilateral and Multilateral Accords on Extradition, Readmission and the Inadmissibility of Asylum Requests. New Issues in Refugee Research, Working Paper No. 10. Geneva: UNHCR, 1999.

http://www.unhcr.ch/cgibin/texis/vtx/home/+xwwBmedmJ69wwwwwwwwwwwwhFqo20I0E2gltFqo Gn5nwGqrAFqo20I0E2glcFqocwDmtGnDDzmxwwwwwww/opendoc.pdf>

Lavenex, Sandra, Security Threat or Human Right? Conflicting Frames in the Eastern Enlargement of the EU Asylum and Immigration Policies. Working Paper, Florence: Roman Schuman Centre for Advanced Studies, 2000.

Melis, Barbara, Negotiating Europe's Immigration Frontiers. The Hague et al.: Kluwer Law International, 2001. 
Mitsilegas, Valsamis, 'The Implementation of the EU Acquis on Illegal Immigration by the Candidate Countries of Central and Eastern Europe: Challenges and Contradictions', 2002 Journal of Ethnic and Migration Studies 28, 665-682.

Morrison, John/Beth Crosland, The Trafficking and Smuggling of Refugees: The End Game in European Asylum Policy? UNHCR Working Paper. Geneva: UNHCR, 2001.

http://www.unhcr.ch/cgibin/texis/vtx/home/opendoc.pdf?tbl=RESEARCH\&id=3af66c9b4\&page=publ

Niessen, Jan, Five Years of EU Migration and Asylum Policy-Making Under the Amsterdam and Tampere Mandates. Paper Prepared for the German Council of Experts for Immigration and Integration (Immigration Council). Brussels: Migration Policy Group, 2004

http://www.migpolgroup.com/publications/default.asp?action=publication \&pubid=141

Noll, Gregor, Rejected Asylum Seekers: The Problem of Return. New Issues in Refugee Research, Working Paper No. 4. Geneva: UNHCR, 1999. http://www.unhcr.ch/cgibin/texis/vtx/home/opendoc.pdf?tbl=RESEARCH\&id=3ae6a0cd0\&page=publ

Rogers, Nicola/Steve Peers, EC Readmission Agreements. In: Nicola Rogers/Steve Peers (eds.), EU Immigration and Asylum Law: Text and Commentary. Leiden: Martinus Nijhoff, 2005 (forthcoming).

Schieffer, Martin, 'Community Readmission Agreements with Third Countries - Objectives, Substance and Current State of Negotiations', 2003 European Journal of Migration and Law 5, pp. 343-357.

Statewatch, 'Voluntary or "Forced" Repatriation to "Safe" Third Countries', 2002 Statewatch Bulletin 12. http://www.statewatch.org/news/2002/nov/14safe.htm

UNHCR, The Application of the "Safe Third Country" Notion and Its Impact on the Management of Flows and on the Protection of Refugees. Background Paper No. 2. Geneva: UNHCR, 2001a. www.unhcr.bg/global_consult/background_paper2_en.htm

UNHCR, Inter-State Agreements for the Re-Admission of Third Country Nationals, Including Asylum Seekers, and for the Determination of the State Responsible for Examining the Substance of an Asylum Claim. Background Paper No. 3. Geneva: UNHCR, 2001b.

http://www.unhcr.bg/global_consult/background_paper3_en.htm 